\title{
Managing Socio-Economic Problems of the Wetland Environment in South Kalimantan
}

\author{
Yety Rochwulaningsih ${ }^{1 *}$, Noor Naelil Masruroh ${ }^{l}$, Fanada Sholihah $^{2}$, Sutejo K. Widodo ${ }^{l}$, \\ and Susilo Budiyanto ${ }^{3}$ \\ ${ }^{1}$ Department of History, Faculty of Humanities, Universitas Diponegoro, Semarang, Indonesia \\ ${ }^{2}$ Center for Asian Studies, Faculty of Humanities, Universitas Diponegoro, Semarang, Indonesia \\ ${ }^{3}$ Department of Agrotechnology, Faculty of Animal and Agriculture, Universitas Diponegoro, \\ Semarang, Indonesia
}

\begin{abstract}
This study examines various problems occurring in wetland clearing and uses in South Kalimantan. In the beginning, the wetland clearing aimed to expand the food crop area in order to implement government policies to meet the food needs. However, it has changed into the capitalist media and transmigration purposes. This study uses a historical perspective composing from heuristic to historiography with an ecological approach. Based on the findings, the land clearing was integrated with the transmigration program which had been started since the 1960s. The argument that can be developed in this study is that wetland-use expansion causes two basic problems in environmental management, namely the large volume of standing water and the relatively high acidity level. This expansion referred to the settlement developed around the wetlands which increasingly could not be controlled by the government. However, ideally, the existing situation had to show that wetland clearing has shifted should balance social, environmental, and economic values, of which the implementation to regulate self-productivity that actually has been running for generations.
\end{abstract}

Keywords: Wetlands; Land-Use; Social Problems; Land-Clearing; Mismanagement.

\section{Introduction}

Topographically, South Kalimantan is an area with land contours in the form of wetlands, which become an important habitat for flora, fauna, as well as humans that make use of them. An important issue arising in efforts to manage wetlands is the urgency of biodiversity living habitat caused by the conversion of forest areas, land degradation, overlapping land use, and management of wetland ecosystems that have not been implemented in an integrated and optimal way by utilizing the existing capabilities,

\footnotetext{
${ }^{*}$ Corresponding author: wulan@live.undip.ac.id
} 
including the surrounding communities. Diverse resources can be useful for animal feed, fish, firewood, non-timber forest products, ecotourism, and flood control, that historically has provided a source of income and livelihood for humans [1]

On the other hand, a stronger penetration of capitalism into all economic sectors, including in the field of oil palm plantations, has helped carry out government programs in promoting the industrial expansion. This policy could be seen during the New Order era from the steps taken by the government by manifesting the major obsession of the government through Five Year Development (Pelita). Massive expansion of capitalism emerged and developed in the plantations in wetlands, such as oil palm plantations [2]. Consequently, various resistance and conflicts among farmers or traditional communities over land tenure emerged, not to mention the increase in plantation industry activities which often gave an impact on the destruction of wetlands in South Kalimantan. The government even imposed a moratorium on plantation activities in wetlands to improve plantation land governance and environmental preservation. The moratorium also applied specifically to oil palm plantations.

This study provides an overview of the wetland scope consisting of peatlands, mangroves, swamps and rivers, but the emphasis on the wetlands is only in peatland and river types. Issues related to peatland ecosystems have not been resolved yet until now, moreover, they are related to land damage due to plantation company activities. It is known that around 9.25 million hectares of peatlands are in the Kalimantan region or $52 \%$ of total land in Indonesia, while South Kalimantan has around 1.48 million peatlands or around 15\% [3]. Several parts of them have experienced severe land degradation that also disrupt the sustainability of management and use of the land potential by the surrounding communities. The government also encourages the efforts of wetland use and management intended for agricultural activities. The agricultural activities in the wetlands have been carried out for generations, of which the nature is still for subsistence and not for commercial yet.

The system of wetland protection and conservation has become a priority for the nations in the world. At least 159 countries have participated in ratifying the Ramsar Convention in 2009 [4], including Indonesia which has already seven Ramsar sites [5]. This is the basis for how wetlands should be used and managed in South Kalimantan, although until now there has not been a single area in South Kalimantan that is included in the Ramsar site. This study explores various socioeconomic issues related to wetland management as part of conservation and land use efforts penetrated by the capitalism, while small communities are used to fulfill their daily needs. Two problems that are still dilemmatic and found yet a role model in its handling.

\section{Literature Review}

The basis of this study emphasizes on the land clearing and the land-use. Therefore, it is better to know how the communities do these things based on the relationship with nature. A study conducted by Djamhuri [6] focuses on the peatland utilization by farmers through the introduction of new technologies. The new technology is an elective alternative in the productivity of farming on peatlands. The introduction includes diversification of plant types and cultivation technology carried out through land and plant management activities. In addition, this study also analyzes farming using the pattern on the plantation land and paddy field. Based on the study, it is found that in general peatland farmers use mixed planting patterns for plantation land and 
yards. While for paddy fields, they use a monoculture-based system. In terms of business analysis, paddy fields are considered more profitable than plantation land.

Correspondingly, the study conducted by Lamsal et al [1] confirms that there is local community participation in wetland conservation in the area around Lake Ghodhagodi, Nepal. This study is important to find the patterns and participation level and to provide economic benefits received by the local communities. This study also assesses what factors affecting the relationship between humans and wetland ecosystems that are considered to have a high dependency. This study argues that the adoption of a wetland environmental conservation system can be carried out on the community (community-based), as has been successfully applied in Bangladesh over the past decade. Implementation of various community-based forestry program has an impact on the fair resource distribution in the wetland environment. Therefore, the orientation of the community participation system should not place the community as a workforce but as an 'owner', therefore, it needs to be empowered for long-term interests.

Lamsal's study is reinforced by the ecological social reality in Kalimantan as presented by Yuliani et al. In the Reformation era, deforestation was a major issue in the management of the forest environment that placed Kalimantan as an island with the most severe forest loss. Still, there were a few areas successful in defending the capitalist penetration land that practiced illegal logging and converted the wetlands into oil palm plantations. This study enriches the literature on land-use change because all this time there is only scientific information about the conversion of oil palm plantations and the response to the rejection of it, whereas description and analysis of the land management success by involving the surrounding community are rarely discussed. This study also directly provides a real example that the impression stating that society is helpless because of financial temptations can be changed. Nevertheless, the role of the community has not been optimal because they have not been able to arrive at the level of planning and policy.

Meanwhile, the planning and policy on wetland management and use are fully under the control of the Indonesian government, both central and regional government, therefore, a legal basis for management and utilization is needed. In a study conducted by Anggara, it is revealed that in the context of protection and management of wetland ecosystems such as peat, it is required systematic and integrated efforts to preserve functions and prevent damage, including planning, utilization, control, maintenance, supervision, and law enforcement. This study emphasizes wetland conservation through the Ramsar Convention 1971 so that the efforts made by the local community and the government become more real and binding.

\section{Research Method}

This study opened discourse on the management and use of wetlands appropriately based on socio-economic issues, especially on peatlands and drainage basin. By using historical and ecological approaches, this study was able to map the socio-economic problems occurring during the New Order era to the present. The problems were in the form of land conflicts between local residents and plantation companies, land damage, natural disasters due to excessive land exploration practices, and the role of the government in the excessive land management and use in Kalimantan. The problems were mapped based on the national, local, or even international newspaper resources 
such as Kompas, Media Indonesia, Tribun, The Strait Times, and others published during the New Order era until now.

Meanwhile, the ecological approach was used to see the role of the community in dealing with the existing ecological problems. This approach was important in defining social-ecological problems in new ways through effective interventions, in other words, the emphasis of this approach lied in the relationship between humans and their environment. At present, an ecological approach is a strategy that not only allows communities to intervene at the micro-level but also at the macro level. In this case, it is in the planning and policy levels. It is important to provide space for the communities to be empowered to feel a sense of ownership and to preserve their natural environment [7]. Therefore, there are two main problems in this study land-use and problems arising because of it.

\section{Result and Discussions}

South Kalimantan's topographic existing conditions dominantly as alluvial plains, lowlands, hilly, and mountainous areas. This area includes swamps that are connected by large and small rivers. One of the largest rivers in South Kalimantan is the Barito River, which flows into the Java Sea. The length of the river covers almost all over of southern and central Kalimantan. As an area known as a thousand rivers, South Kalimantan's toponimically consist of the very unique regional name with nuances of the ocean or waters, such as the use of estuaries, headlands, bays, beaches, uprooted and others. As Mansyur [8] has mentioned, there are several areas named by Kuala Kapuas, Muara Teweh, Tumbang Jangkang, Labuhan Amas, Tanjung Tabalong, Karang Tengah and so on, all of which contain water. South Kalimantan has become an 'open space' for anyone, especially migrants who conducted shipping and trade activities. It is integrated into the inter-islands and international shipping as well as maritime trading systems.

Wetlands use in South Kalimantan is closely related to the habits and traditions of the local community. They have local knowledge that able to manage wetlands created by the interaction of specific environmental issues such as, waterlogging and high acidity levels (in the form of acid sulfate soils) [9]. On the other hand, among the older generations said for those who lived in the wetland area are known as river communities or the water people because of their mobility and daily life that could not be separated from water or rivers. The uncontrolled use and management of wetlands stems from the expansion of plantation capitalism and the increasingly massive opening of transmigration lands.

\subsection{Capitalism Expansion in the Swamps}

The capitalist interests in clearing land is aimed to the benefit of the plantation industry. This section refers an explanation to plantation businesses carried out with dominance in oil palm plantations and rubber. Penetration of capitalism continued and increasingly peaked in 1998, since the opening of wetlands for capitalism expansion activities. It was carried out by burning land which subsequently became a new habit. It was done as the method to utilize land with unique characteristics. It is getting worse that the capitalists are actually 


\section{build their business systems from upstream to downstream, so that the problem become more complex.}

As had been reported by national and local mass media, since the 2000s extreme ecosystem damage of the wetlands have occurred in South Kalimantan. Various nongovernmental organizations (NGOs) and environmental activists urged the government to stop the licensing for plantation companies in the wetlands. For peatlands, there were at least 18 companies holding the right of exploitation (HGU) with a concession area of 27 thousand hectares respectively [10]. These land areas did not include swamps and the area around the river which also becoming part of the wetlands. Figure 1 shows the wide distribution of oil palm land that was recorded by the Government of South Kalimantan in 2006.

According to Figure 1, it appears that the activity of the plantation industry is dominated by large-scale private plantations. While the position of community plantations here is cultivated by residents to be used as plantation land and for their interests [2]. The phenomenon of swamp palm oil development occurs in several districts in South Kalimantan, such as Banjar, Hulu Sungai Selatan, Barito Kuala, Tanah Laut, and Hulu Sungai Utara districts. There were 201,813 hectares of swamp areas that had obtained a palm oil consensus in 2012. This arising discussion by the environmentalist and NGOs who opposed the granting of permits because it threatened agricultural land which would have a long impact on local food security. Not only in South Kalimantan, this phenomenon has experienced in almost all swamps in Kalimantan. Basically, the difficulty of growing food crops has been felt since the 1980 s, around $50 \%$ of people in the swamp or peat area chose to rely on their lives from cutting down the wood in the forest, only about $30 \%$ who carried out agricultural activities. This condition took place before the community became acquainted with the oil palm and rubber business [11].

The opening of swamp plantations has shifted the farming patterns of the local people which previously they grew vegetables and raised livestock. Based on community use, wetlands include as productive land category, which indeed must continue to be developed and encouraged to increase productivity and other added values. The phenomenon that has occurred since 2011 is the increasingly widespread business of oil palm plantations on swamps. That fact has denied the 1971 Ramsar Convention on the Conservation of Wetlands.

\section{Palm Oil Area in South Kalimantan during 2006}

$74 \%$

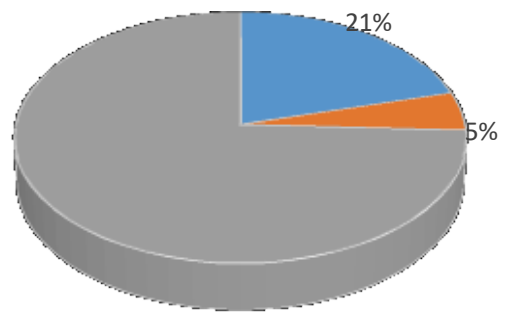

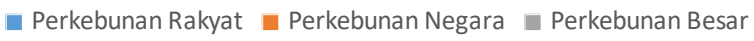

Fig. 1. Palm Oil Area in South Kalimantan during 2006. 


\subsection{Clearing land for transmigration}

Wetland clearing is integrated with the transmigration program, which started in the 1960s. During the New Order era, the transmigration program by opening new land became increasingly legitimate to be carried out. In general, the transmigration program provides facilities for the migrants in the form of housing, agricultural land for food crops, estate crops, life insurance, and other means of living necessities. This program, has been held regularly and has opportunities for collaboration with plantation companies as partners. Agricultural and plantation systems using wetlands, in this regard is the peatlands, have been carried out with a variety of models, from the Nucleus Estate Smallholder (NES) model in 1976 to the Nucleus Plantation (PIR) model in 1980. However, both models have been stopped since 1990 [12]. Both models have been applied and must accommodate plantation companies that can collaborate with farmers with an orientation on increasing plantation productivity. The migrants were directed to develop the production mode of oil palm plantations and leave the traditional agricultural mode production of paddy fields. According to the governmente, it should be shifted because they were considered uneconomic [13].

During the post-independence era, the Indonesian government conducted a more detailed survey of the wetland investigation. At that time, the team was led by several Dutch experts who were still living in Indonesia, including Schophuys in 1952 who had promoted a polder system for developing wetlands or swamps. The history of wetland development, based on the period, method, and development areas. According to Haryono et al. [14], there are three periods in the development of the program, it is including 1945-1960s, 1969-1995s, and 1995-2000s [14]. Since 1969, the government has succeeded in opening around 1.2 million hectares of potential wetlands which are integrated with the transmigration program. In South Kalimantan, during the area of wetlands opened by the government reached 3,000 hectares which is generally used for housing, developing rice, coconut and rubber commodities. Until now, the undiscovered area is still quite large, although some have no potential to be developed. However, a new problem arises in land clearing that the number of land-cleared become much more limited. As a result, many transmigration projects in wetlands have failed due to damaged peatland structure, water resources management limitations, land containing high sulfuric acid, and lower fertility.

\subsection{Land Damage and the Mismanagement Permits}

While the local and central government continue to expand the oil palm plantation area which targeted to increase capital income, it also become threats to the existence of wetlands. Reports on land damage in South Kalimantan also occurred in drainage basin (DAS), it causing some areas prone to flooding. One example of the damages such as in Cengal Batulicin drainage basin might cause three regencies prone to flooding, namely Tanah Bumbu, Tanah Laut and Kotabaru. Moreover, $335.88 \mathrm{~km}$ long river in the South Kalimantan region was reported to have turned into a mining pit that could 
be seen in the imposition of mining permits on $41 \%$ of forestland [15]. The objective existing conditions and the emergence of reports on land damage, has encouraged the government to revise the pattern of management and utilization of water resources in 2018 and produce Law No. 17 of 2019. The changes are related to the reinforcement on wetland conservation efforts in the form of utilization, damaged water resources control by involving the community, private sector, and the government.

\section{Conclusions}

The main issues surrounding the wetlands management and use are the expansion of capitalism by the plantation industry and the clearing land for transmigration programs, even though transmigration lands are increasingly difficult to open due to the absence of land nowadays. In its development, land clearing for the oil palm and rubber plantation industry has increasingly expanded and conversed of agricultural land for food crops. This condition influences the livelihood as food crop farmers since the 1980s. They have changed to become oil palm and rubber plantation farmers. Coupled with the opening of the transmigration program which has confiscated wetlands in South Kalimantan. Both the two issues, it becomes even more complex when the damage as reported so far and connected with mismanagement permits, both for plantation and mining businesses. It has become the major issues discussed in the local and national level.

\section{Acknowledgement}

Institute for Research and Community Service Universitas Diponegoro (Research for International Publication Higher Reputation) 2020 has funded this research and publication.

\section{References}

1. P. Lamsal, K. P. Pant, L. Kumar, and K. Atreya, Ecol. Soc. 20, (2015)

2. Z. Zubir, Masyarakat. Indonesia. 43, (2017)

3. A. S. E. Sudrajat and S. Subekti, J. Planol. 16, 219 (2019)

4. J. T. A. Verhoeven and T. L. Setter, Ann. Bot. 105, 153 (2010)

5. A. S. Anggara, Mimb. Huk. 30, 246 (2018)

6. M. Djamhuri, 97 (1996)

7. J. T. Pardeck, An Ecological Approach for Social Work Practice (1988)

8. M. Mansyur, M. Mursalin, and W. Subroto, Sahang BanjarBanjarmasin Dalam Jalur Perdagangan Rempah Lada Dunia Abad 18 (Pemerintah Kota Banjarmasin, Banjarmasin, 2019)

9. U. Chokkalingam, Kebakaran, Mata Pencaharian, Dan Kerusakan Lingkungan Pada Lahan Basah Di Indonesia: Lingkaran Yang Tiada Berujung Pangkal (Bogor, 2004)

10. Media Indonesia. (2019)

11. S. L. Jewitt, D. Nasir, S. E. Page, J. O. Rieley, and K. Khanal, Int. For. Rev. 16, 405 (2014)

12. Kompas (2009) 
13. S. Wartiharjono, Masyarakat, Kebud. Dan Polit. 30, 84 (2017)

14. H. Haryono, M. Noor, H. Syahbuddin, and M. Sarwani, Lahan Rawa: Penelitian Dan Pengembangan (Badan Penelitian dan Pengembangan Pertanian, Jakarta, 2013)

15. Media Indonesia. (2018) 